Marzena PYTEL-KOPCZYŃSKA

Piotr OLEKSIAK

\title{
2.1. AGE MANAGEMENT AS AN INTEGRAL PART OF CORPORATE SOCIAL RESPONSIBILITY
}

\section{Summary}

The purpose of this article is to present an overview of the issues of age management as an essential and integral element of corporate social responsibility organization to employees. The implementation of the concept of age management is particularly important in terms of increasing the participation of mature workers $50+$ in the labor market, from which it increasingly begins to depend on the smooth functioning of the organization. On the other hand, as companies are beginning to recognize the need to use a variety of tools exploit the potential of employees, depending on their age. The article was based on a literature review of studies of the problem and the results of secondary research.

Keywords: CSR, HRM, age management

\section{Introduction}

In the current conditions of economic life featuring with high competitiveness and high variability of external and internal conditions, each organisation has to take various and multidirectional actions which allow it to survive and strengthen its position in the market in the long-term (strategic) approach.

The initiation of the concept of Corporate Social Responsibility (CSR) is based on sustainable and conscious actions oriented not only on the financial profit and economic aspects of the organisation but also taking into consideration the needs and requirements of various interested parties outside and inside the company (employees, shareholders, suppliers, customers, contractors or local society) in the social, ethical or ecological aspect, comprises one of such actions. Of course, initiation of the concept of Corporate Social Responsibility brings a set of benefits to the organisation which may include (Responsible Business Forum):

- Increase in the investors' interest towards the companies which try to create positive image and relations with the surroundings and connected financial credibility with social credibility;

- Increase in the consumers' and interested party's loyalty as a result of appropriate level of trust to the given company and its image;

- Increase in the competitive position as a result of creating the company image on the basis of the rules of corporate social responsibility; 
- Shaping the appropriate relations with local authorities and community by taking long-term social investments aimed to root positively in the society and obtaining the acceptance of its residents;

- Shaping a positive organisation image among its employees by using different kinds of tools of motivating other than the financial one, the result of which is obtaining and keeping the best employees in the organisation;

- Shaping the appropriate organisation culture based on trust, responsibility or transparency for all interested parties.

The external dimension of the organisation, i.e. actions taken towards the organisation employees is a significantly important element of corporate social responsibility (Gadomska-Lila, 2012). The nature of these actions may be multidimensional referring to the employment and remuneration conditions, keeping balance between work and personal life, creating the employees' engagement in management of the company, shaping appropriate conditions in the scope of safety and health, education and professional development or also in the area of satisfaction and communication and supporting employees' voluntary work.

At present, the initiation of the age management in the organisation is becoming a more and more important element of actions in the scope of corporate social responsibility towards the employees.

Age management is defined as an element of human resources management and more precisely the element of managing the diversity which consists at first in the performance of various actions enabling to use human resources in companies in a more rational and effective way thanks to considering the needs and possibilities of employees at different age (Liwiński and Sztanderska, 2010b). The reasons for this are the permanent increase in the share in the labour market of mature employees, i.e. being at the age of at least 50 years (50+). What is more, the employers notice the possibility of the effective use of professional potential of the employees by using different kinds of tools from the scope of human resources management depending on the employees' age.

Age management may be considered at the level of organisation and policy of labour market. The actions in order to keep the ability to work with the consideration of permanently shaping employee's abilities are called the age management systems (Kędziora, 2010). On the basis of data referring to the Dynamics of demographic changes in the EU state sit May be stated that the age group of older employees in years 2010 - 2030 will increase by about $16.2 \%$ whereas the falling tendency was show for other age groups ( 40 - 54 years old - from $5.4 \%$ to $14.9 \%$ for age $25-39$ years old). The increase in the percentage of employees $50+$ is caused by the increase in the life expectancy and the fall in fertility rate (Ilmarinen, 2012).

As it results from the research carried out at the group of 1,205 surveys, the work ability index (WAI) is strongly connected with the employee's age. In this research, the respondents were to specify what their level of work ability is. It amounted to about $42.3 \%$ and $40.6 \%$ respectively for the youngest age group (to 29 years old) for both men and women, for the next group (to 39 years old) it is $41.4 \%$ and $40.5 \%$. For persons at the age to 49 years the situation is as follows: $38.5 \%$ for men and $39.5 \%$ for women whereas in the oldest age group the difference is not big and amounts to $37.6 \%$ 
for men and $37.75 \%$ for women. As it is possible to see, the ability to work (according to the respondents' answers) falls together with the surveyed person's age whereas the value of about $40 \%$ corresponds to "good ability to work" (Zus, 2014).

According to the results of the research performed by Randstad, 93\% of the representatives of the tested companies employing mature workers agree with the statement that employees $50+$ are precious specialists and $41 \%$ of tested companies think that their functioning efficiency benefits from employing the mature persons (Randstad, 2014). According to many specialists, the demographic changes will have a significant influence on the functioning of companies the competitiveness of which will depend on the effective use of older employees and maintaining their abilities. Thus, everybody will have contact with the problem of ageing societies but the companies, which prepare their strategies, internal procedures, and policy to the coming changes will obtain competitive advantage (Jaworska, 2010).

In Poland, similarly as in other European countries, the actions are taken which enable the introduction of solutions profitable for older employees, without limiting the chances to enter the labour market for young employees. The Union Initiative EQUAL, which is a part of the strategy of the European Union for the benefit of creating bigger number of better workplaces and providing the wide access to them, without the discrimination of potential employees, may constitute the example of it. The solutions proposed in this programme are aimed to shape the employers' and employees' awareness of the necessity to manage the age efficiently in such a way to provide the company development and maintaining the workplaces (Szmidt, 2010, Grotkowska, 2013).

\section{Prerequisites of age management in the organisation}

The widespread of age management is determined with a few basic factors which may comprise (Litwiński and Sztanderska, 2010a):

- Workforce ageing - within the next 20 years the ageing and decrease in the number of employees will occur in the European Union which will determine the necessity of a new approach to the human resources management by the companies as well as the state. In connection with the fall in the number of young people entering the labour market, the employers will be forced to take actions to encourage the older persons to stay in the labour market;

- Low professional activity of older employees;

- Necessity to prevent discrimination due to age;

- Adapting to the amendments of the state policy concerning employment.

There are many prerequisites in favour of initiating age management in the organisation both from the points of view of the employee and the organisation. 
From the company point of view, the age management (particularly when it comes to employees 50+) has the following advantages (Akademia Rozwoju Filantropii w Polsce):

- Increases the employees' work efficiency in the organisation by effective use of professional potential, creating good atmosphere at work, motivating or limiting the existence of generations' conflicts;

- Decreases the labour costs as a result of decreasing the employees' absence (by appropriate health prevention or adapting the work time to the employees' needs);

- Keeps the valuable employees at work, the ones possessing great experience which they may present to younger employees;

- Optimises the employment structure by stricter adapting of employee's competences to the work place;

- Decreases the employees' fluctuation and in a consequence reduces the recruitment and selection costs.

The above benefits cause the creation of the positive image of the company both it its internal and external surroundings. The organisation increases the efficiency of its functioning by creating working trams of the intergeneration nature which connect the work potential of young and elder employees. Thanks to using the variety of age (and professional experience) of the employees, the organisation possesses the intellectual capital creating the integrated structure, able to effective development and synergic work (Karpowicz, 2010).

It is also necessary not to forget about the advantages of using the age management for employees (especially the elder ones). Thanks to such actions, the employees have the possibility to satisfy their needs by obtaining incomes, social and professional development, keeping further professional and social activity at the age 50+ (also after the retirement) or at last shaping the positing feeling of their value and usefulness at the labour market and in the organisation. On the other hand, the employer should try to deepen the knowledge about elderly persons as well as to break negative stereotypes connected with their productivity, which is not easy because the domination of young, dynamic, flexible (as it refers to changes) employees who often have a negative attitude towards the work with elder people, occurs in the majority of working environments (Karpowicz, 2012).

It should be remembered that the appropriate information policy, especially as it comes to managerial staff and organisation employees, the purpose of which is at first to explain the purpose and procedures of the intended changes as well as to indicate the employees' influence on their performance, is a significant element of introducing the age management in the organisation. For this purpose, the organisation should use a few communication channels at the same time, e.g. electronic mail, Internet forums, collective brochure, employees' opinion or satisfaction polls meetings with the managerial staff and employees or communication in a form of collective negotiations (Kobus-Woszczyk, 2012). 


\section{Surfaces or tools of employees' age management}

Age management covers numerous surfaces within which various tools and actions may be applied. These surfaces are at first (Kędziora-Łojkowska, 2010):

- New employees' recruitment and selection;

- Trainings and development of professional career;

- Flexible forms of employment and work modernisation;

- Health care and promotion;

- Designing work places and internal moves between positions;

- Ending the employment and retirement.

The equality of elder persons in the access to vacancies, i.e. no discrimination of such persons in connection with age becomes a main assumption in the case of recruitment and selection.

It is very important due to the fact that discrimination connected with the age is a serious problem at the stage of recruitment to work. In accordance with the results of job advertisements monitoring carried out by Polish Society of Antidiscrimination Law in 2009, about 25 thousand incorrectness were noticed in over 60 thousand analysed advertisements which could lead to discrimination in employment out of which 10 per cent referred to age (Kędziora, 2010).

In order to avoid the above discrimination, the organisation may use various tools such as (Litwiński and Sztanderska, 2010a):

- Constructing competence profiles of work positions and preparing job offers on the basis of them;

- Limiting to the minimum qualification requirements in the recruitment advertisements which would exclude the persons at certain age from applying and replacing these requirements with competence requirements;

- Placing job offers in media which would reach persons at various age groups (placing recruitment advertisements also in traditional press);

- Cooperation with such recruitment and selection agencies which would guarantee no discrimination in the recruitment and selection process;

- Avoiding comments referring to the candidate's age or assessing the candidate e.g. by the competence matrix or psychometric tests during job interviews;

- Taking advantage of public programmes supporting the employment of elder persons (the example of which may be exemption from the contributions to the Labour Fund and Guaranteed Employee Benefits Fund for the first year after signing the agreement which is vesting to the companies employing a new employee at the age over 50 (Schimanek et.al, 2015).

As it comes to the development of employees, the initiation of age management should result in providing the training for elder employees just as to the younger employees, providing the possibility to learn during the whole professional career or at last adapting the training methods to the possibilities of the elderly persons. In this scope the company make take such actions as - abolishing the limit in the access to trainings, motivating employees for further professional development, adapting training programme (methods, place and time) to the needs of employees arising from their age or their individual path of professional development and taking advantage of the 
knowledge and experience of elder employees in planning and organising trainings (Litwiński and Sztanderska, 2010c).

According to the research carried out on the group of 500 employees at the age 50+ ( 250 women and 250 men), $20 \%$ of employees stated that they feel discriminated in their companies and only $25 \%$ of surveyed employees admitted that the trainings were addressed to them). It is worth noticing that on the basis of respondents' answers it turned out that only $20 \%$ of respondents were really encouraged to extend their knowledge (whereas about $40 \%$ of respondents indicated the trainings to extend or update their knowledge referring to the performed work, whereas the smallest number of educational events addressed to the surveyed employees was connected with the information referring to the care for health) (Hildt-Ciupińska and Bugajska, 2013).

As it comes to shaping the professional career, the age management in the company should try to support the professional career of both elder and younger employees or to increase the employees' level regarding to all employees. Performing such a strategy, the company may- recognise the employees' professional plans and adapt them to the professional career path, take advantage of the assistance of professional councillors at planning the professional career path, transfer all information about the possibilities of promotion to the employees or finally, also depend the employee's promotion on his/her efficiency or competences (and not on the age or length of work) (Litwiński and Sztanderska, 2010d).

The matters connected with the forms of employment are a significant element of programmes connected with age management in the organisation. It is tried at this surface to use flexible forms of employment which would include the changing employee's age (and at the same tome would enable to join the professional work and personal life). The company may use the following actions in this scope:

- Connecting the workers' employment in the flexible forms with their needs (and not age);

- In the case of elder persons decreasing the daily or weekly period of work time;

- Gradual decrease in the work time of elder people at the age directly preceding the retirement;

- Exempting the elder persons from overtime;

- Striving to adapt the work time to the possibilities of the elderly persons individually;

- Granting the paid leaves for the elder persons according to the special rules;

- Employing the elderly persons for the limited period of time or for the time to perform certain tasks.

The promotion and health care comprise the next, important part of the age management programme, their basic objective is to optimise the work organisation towards maximising the employees' efficiency at the same time keeping their good health and ability to perform work. On the basis of the survey research conducted on the representative group of 1,138 employees from 250 companies from two age groups: the younger one (control group, $49.8 \%$ of respondents) and the older one (examined group, $50.2 \%$ of respondents), it turned out that the older employees do not differ significantly from the younger employees as it comes to the attitude to health. The answers of the majority of respondents (66-70\%) indicated the so called 
promotional health approach so perceiving it with the consideration of the understanding of various types of reserves, treating in as something positive and able to develop. The other respondents took the lack of disease as a concept of health, which is close to the statement "health in vacuum" used by Herzlich (Korzeniowska, 2004).

This area is important due to the fact that the possibilities of performing the work by the employee change with age, which is mainly caused by the reduction of the ability and physical fitness and some elements of psychophysical fitness. Despite the fact that the ability to work deteriorates with age, the demographic and economic factors determine the necessity to extend the period of professional activity, especially by encouraging the growing number of elder employees to stay in the employment (Bugajska et.al., 2010).

The actions in favour of this may be performed among others by monitoring the dangers in the work place and the workers' health condition, the assessment of the worker's ability to work on the basis on the health condition (and not age), by using the help of expert of the labour medicine, by employees' training concerning OHS rules or taking solutions promoting the provision of the workplace ergonomics (Zawadzki, 2009).

Two last surfaces of the age management comprise the move between positions and retirements. As far as moves between positions are concerned, their causes are usually the limits of the employee's work ability (because of the lack of competence or the health condition) or actions towards further professional development of the employee. The moves between the positions should lead to permanent maintenance or increase in the worker's ability and in particular, as a result of extension of the competences to provide better conditions of healthcare.

Whereas ending the employment and retiring should be conditioned at first with the assessment of the employees; work productivity or level of competences (and not age including also achieving the retirement age). The company should also take into consideration the possibility to change the form of employment to the flexible form (limited time, tele-work) instead of dismissal. Other actions in this scope comprise the initiation of the outplacement programme or preparation of the employee for retirement.

\section{Conclusions}

Age management as the element of social corporate responsibility towards the employees in the current conditions of the companies functioning at the market is becoming a very important element of creating the positive image of the company at the markets and the effective use of the human capital. Using this tool brings benefits both for the employee and the organisation. In the case of the employees, they obtain the possibility of personal and professional development, the maintenance of longer professional activity, satisfying the needs connected with remuneration or promotions or feeling the employment security. 
In the case of organisations, the benefits of the age management comprise the effective and complex use of the potential of different workers' groups, decrease in the employees' fluctuation or absence, creation of efficient workers' team, rational planning of consequences or finally, creation of positive image of the company at the market for which the employee is not a cost but a precious resource and investment in the future.

Of course, age management in the organisation is not an easy task, and the basis of its success should be obtaining the support of the company management or all employees for this type of actions. The managerial staff should be trained in the aspect of age management, appropriate information policy should be prepared or finally, age management should be included into the development strategy of the organisation and the strategy of human resources management.

\section{References}

1. Akademia Rozwoju Filantropii w Polsce, Zarządzanie wiekiem - szansa dla przedsiębiorców. Mini przewodnik zarządzania wiekiem, http://solid.home.pl/pdf4/miniprzewodnik.pdf, access from 31st May 2015.

2. Bugajska J., Makowiec-Dąbrowska T., Wągrowska-Koski E. (2010): Zarządzanie wiekiem w przedsiębiorstwach jako element ochrony zdrowia starszych pracowników, „Medycyna Pracy”, 61 (1), pp. 55-63.

3. Gadomska - Lila K. (2012): Społeczna odpowiedzialność biznesu wobec pracowników,„Management and Business Administration. Central Europe”, 2/ (115), pp. 41-52

4. Grotkowska G. (2013): Analiza porównawcza zmian sytuacji osób 45+ na rynkach pracy w Polsce oraz w wybranych krajach UE intensywnie promujących politykę zarządzania wiekiem, PARP, Warszawa.

5. Hildt-Ciupińska K., Bugajska J. (2013): Evaluation of activities and needs of older workers in the context of maintaining their employment, "Medycyna Pracy", 64 (3), pp. 297-306.

6. Ilmarinen J. (2012): Promoting active ageing in the workplace, European Agency for Safety and Health at Work, https://osha.europa.eu/en/tools-and-publications/publications/articles/promotingactive-ageing-in-the-workplace access on 31st May 2015.

7. Jaworska, J. (2010): Rola pracodawców w strategiach wydłużania aktywności zawodowej osób 50+. in: Zarządzanie wiekiem i nie tylko, Akademia Rozwoju Filantropii w Polsce, Warszawa.

8. Karpowicz E. (2010): Kompleksowy program aktywizacji osób starszych, 50+. Raport nr3. Zarządzanie pracownikami w wieku 50+ -perspektywa pracodawcy, Akademia Leona Koźmińskiego, Warszawa.

9. Karpowicz E. (2012): Podmioty odpowiedzialne za wspieranie aktywizacji zawodowej osób starszych 50+ w opiniach pracodawców i pracowników, in Szmidt C. (ed), Raport końcowy. Kompleksowy program aktywizacji osób starszych 50+, Akademia Leona Koźmińskiego, Warszawa. 
10. Kędziora K. (2010): Wprowadzanie przez polskich pracodawców systemów zarządzania wiekiem. Możliwości i braki, Stowarzyszenie Interwencji Prawnej, Analizy, Raporty, Ekspertyzy 7 (36).

11. KędzioraK., Łojkowska M. (2010): Zarządzanie wiekiem w pytaniach i odpowiedziach. Informator dla pracodawców, Stowarzyszenie Interwencji Prawnej, Warszawa

12. Kobus S., Woszczyk P. (2012): Zrównoważony rozwój firmy. Zarządzanie wiekiem jako element strategii CSR, „Personel i Zarządzanie” 7/268 pp. 46-49.

13. Korzeniowska E. (2004): Sposoby myślenia i postępowania w sferze zdrowia starszych pracowników średnich i dużych firm, „Medycyna Pracy”, 55 (2), pp. 129- 138.

14. Litwiński J., Sztanderska U. (2010a): Wstępne standardy zarządzania wiekiem w przedsiębiorstwach, PARP, Warszawa.

15. Liwiński J., Sztanderska U. (2010b): Zarządzanie wiekiem w przedsiębiorstwie, PARP, Uniwersytet Warszawski, Warszawa.

16. Litwiński J., Sztanderska U. (2010c): Zarządzanie wiekiem w przedsiębiorstwie. Kształcenie ustawiczne, PARP, Uniwersytet Warszawski, Warszawa.

17. Litwiński J., Sztanderska U. (2010d): Zarządzanie wiekiem w przedsiębiorstwie. Rozwój kariery zawodowe, PARP, Uniwersytet Warszawski, Warszawa.

18. Randstat (2014):, Zarządzanie wiekiem jest coraz ważniejsze dla sprawnego funkcjonowania firmhttp:/www.pulshr.pl/zarzadzanie/zarzadzanie-wiekiem-jestcoraz-wazniejsze-dla-sprawnego-funkcjonowania-firm,18823.html, access on 31st May 2015.

19. Responsible Business Forum, http://odpowiedzialnybiznes.pl/haslaencyklopedii/spoleczna-odpowiedzialnosc-biznesu/, access on $31^{\text {st }}$ May 2015.

20. Schimanek T., Kotzian J., Arczewska M. (2015): Zarządzanie wiekiem skierowane na osoby $50+$. Poradnik dla małych i średnich przedsiębiorców i nie tylko, Akademia Rozwoju Filantropii w Polsce, Warszawa.

21. Szmidt C. (2012): Raport końcowy. Kompleksowy program aktywizacji osób starszych 50+, Akademia Leona Koźmińskiego, Warszawa.

22. Zawadzki K. (2009): Zarządzanie wiekiem w organizacjach gospodarczych, in Wiśniewski Z. (ed.): Zarządzanie wiekiem w organizacjach wobec procesów starzenia się ludności, TNOiK, Toruń.

23. Zus (2014): Wydłużony okres aktywności zawodowej pracowników 50+ a warunki pracy z uwzględnieniem obszarów, w których występuje zwiększone ryzyko wypadków przy pracy i chorób zawodowych oraz zagrożeń powodujących obniżenie zdolności do pracy, CIOP, Warszawa 